\title{
Sharing of virulence-associated properties at the phenotypic and genetic levels between enteropathogenic Escherichia coli and Hafnia alvei
}

\author{
M. J. ALBERT, S. M. FARUQUE, M. ANSARUZZAMAN, M. M. ISLAM, K. HAIDER, K. ALAM, \\ I. KABIR and R. ROBINS-BROWNE* \\ International Centre for Diarrhoeal Disease Research, Bangladesh, GPO Box 128, Dhaka 1000, Bangladesh and \\ "Royal Children's Hospital, Parkville, Victoria 3052, Australia
}

\begin{abstract}
Summary. Seven strains of Hafnia alvei isolated from diarrhoeal stools of children resembled enteropathogenic Escherichia coli (EPEC) in that they produced attaching-effacing (AE) lesions in rabbit ileal loops and fluorescent actin staining in infected HEp-2 cells. In addition, a DNA probe from a chromosomal gene required by EPEC to produce AE lesions, hybridised to chromosomal DNA from all seven $H$. alvei strains. These findings indicate that there is a sharing of virulence-associated properties at the phenotypic and genetic levels by $H$. alvei and EPEC. $H$. alvei strains with these properties should be considered diarrhoeagenic.
\end{abstract}

\section{Introduction}

Enteropathogenic Escherichia coli (EPEC) strains are an important cause of childhood diarrhoea and characteristically are unable to produce heat-labile enterotoxin (LT) or heat-stable enterotoxin (ST), or express Shigella-like invasiveness. ${ }^{1}$ However, some strains produce a shiga-like cytotoxin. ${ }^{2}$ The majority of EPEC possess a plasmid of $c .60 \mathrm{MDa}$ associated with localised adherence (LA) to cultured $\mathrm{HeLa}$ or HEp-2 cells. ${ }^{3}$ An EPEC adherence factor (EAF) probe constructed from this plasmid shows good correlation with LA in tissue-culture assays. ${ }^{4}$ Furthermore, EPEC induce attaching-effacing (AE) lesions in the intestinal mucosa of affected animals. ${ }^{5}$ These lesions are characterised by intimate attachment of bacteria to the enterocyte with the resultant destruction of microvilli, cupping and pedestal formation of plasma membranes, and accumulation of electron-dense fibrillar material in the terminal web adjacent to attached bacteria. The fibrillar modification probably involves polymerisation of actin filaments, which can be detected in cultured cells by a fluorescent actin staining (FAS) assay. ${ }^{6}$

The genes required to produce the $\mathrm{AE}$ lesion are located on the bacterial chromosome. ${ }^{7}$ Although both LA (plasmid-borne) and AE (chromosomal) properties are required by EPEC for full expression of enteropathogenicity, EPEC unable to cause LA retain the ability to cause diarrhoea, albeit less effectively than strains which possess the LA phenotype. ${ }^{8}$ It appears that the plasmid-associated LA factor may facilitate initial contact of the bacteria with the mucosa, after which the chromosomally encoded factor(s) produce the AE lesions. ${ }^{9}$

Recently, Jerse et al. ${ }^{10}$ used transposon mutagenesis to identify a chromosomal gene that is required by EPEC strain JPN15 (a plasmid-free derivative of EPEC strain E2348/69, serotype O127:H6) to produce AE lesions. This gene, termed eae, comprises a 2817-bp open-reading frame capable of encoding a $102-\mathrm{kDa}$ protein. A $1-\mathrm{kb}$ probe derived from this region hybridised to all E. coli strains of EPEC serogroups which demonstrate AE lesions, as well as to other pathogenic $E$. coli that produce these lesions, such as enterohaemorrhagic E. coli (EHEC) and E. coli RDEC-1 (an EPEC of weanling rabbits).

Recently, we described a strain of Hafnia alvei (referred to as 19982 in this report), isolated from the stool of a child with diarrhoea, that produced diarrhoea in RITARD rabbits and whole intact rabbits. ${ }^{11}$ This strain did not have any recognised conventional virulence-associated properties, such as LT, ST, shiga-like toxins (SLTs) or shigella-like invasiveness of, or adherence to, cultured HeLa cells. However, histological and electronmicroscopic examinations of intestinal tissues from diarrhoeic rabbits and from inoculated small intestinal loops of adult rabbits showed typical AE lesions characteristic of EPEC. ${ }^{11}$ We have since isolated six more strains of $H$. alvei from stools of children with diarrhoea. We characterised these strains and investigated the sharing of virulence-associated properties with EPEC at the phenotypic and genetic levels. 

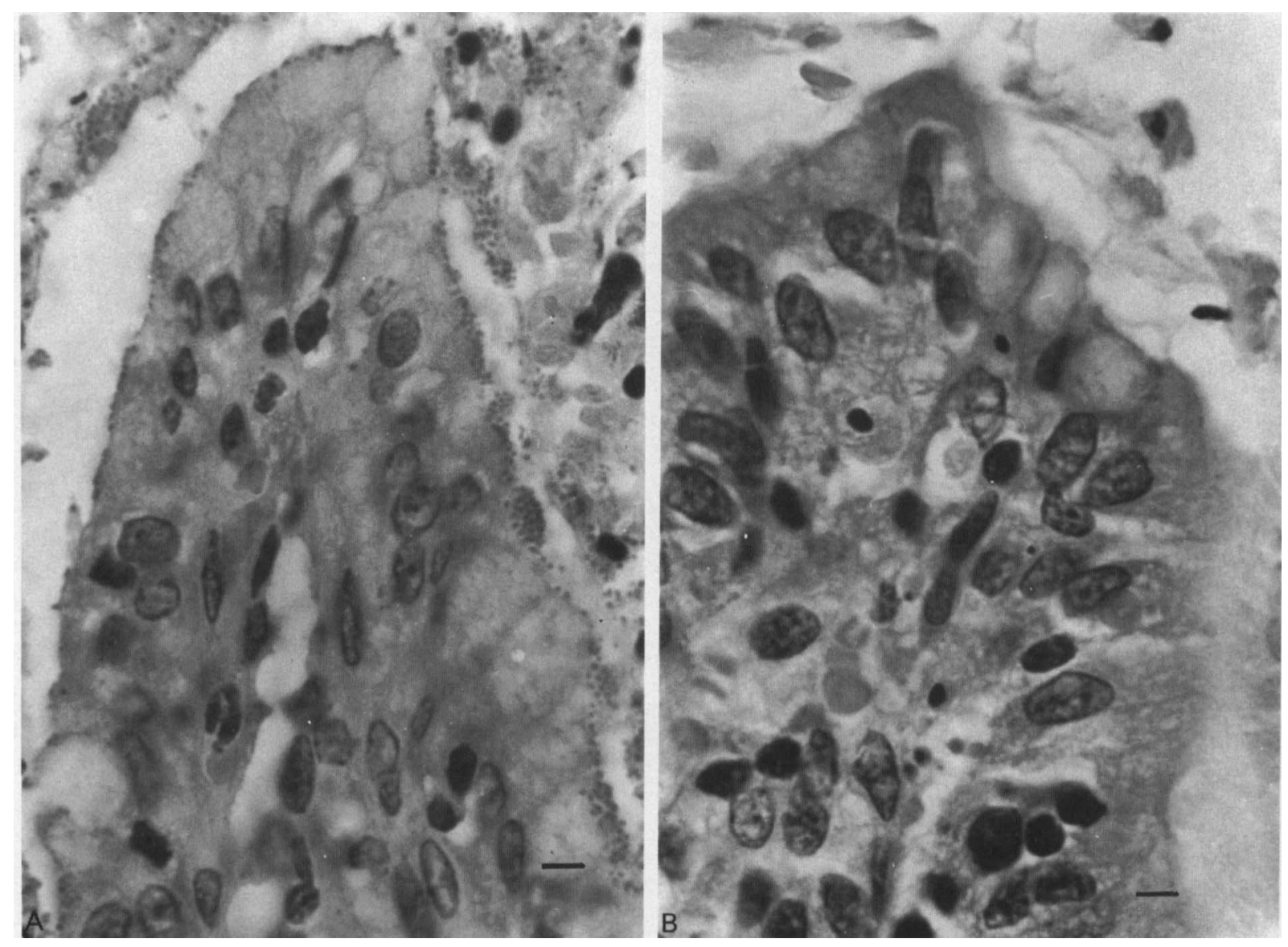

Fig. 1. Ileal loop section (A) from a rabbit inoculated with $H$. alvei strain 10790, compared with the ileal loop section inoculated with nonpathogenic E. coli K-12 (B). Note bacterial attachment and effacement of enterocytes in A, compared with no bacterial attachment to enterocytes in B. (Bar, $6 \mu \mathrm{m}$; haematoxylin and eosin stain).

\section{Materials and methods}

\section{Isolation of $H$. alvei}

$H$. alvei strains were isolated from the stools of six children with diarrhoea. The stools were cultured for enteric bacterial pathogens by standard methods ${ }^{12}$ and $H$. alvei was identified as described previously. ${ }^{11}$ The $H$. alvei strains were designated as $38 / 90,9194,12502$, $10790,924 / 91$ and 10457 . One patient also yielded Aeromonas sobria on stool culture, but the other patients did not yield any recognised bacterial pathogens.

Clinical histories were available for five of the children, all of whom were $<5$ years old. Three children had watery diarrhoea with mild dehydration which was corrected by oral fluid; the other two had mucoid stools, but no dehydration, and were treated with antibiotics. Of the children with mucoid stools, one was diagnosed as having post-measles diarrhoea, the other was infected with $A$. sobria.

\section{Enterotoxigenicity assay}

Bacteria were grown in Trypticase Soy Broth supplemented with yeast extract $0.6 \%$ (TSB; Gibco) at $37^{\circ} \mathrm{C}$ for $20 \mathrm{~h}$ with shaking. Cell-free culture filtrates and polymyxin $B$ extracts of cell pellets ${ }^{13}$ were tested in mouse adrenal tumour $\mathrm{Y} 1$ cells for $\mathrm{LT},{ }^{14}$ in suckling mice for ST, ${ }^{15}$ and in HeLa cells for SLTs. ${ }^{16}$

\section{Enteroadherence assay}

Adherence to HeLa cells was tested by the method of Cravioto et al. ${ }^{17}$ Briefly, HeLa cell monolayers were inoculated with an overnight bacterial culture grown in Luria broth at $37^{\circ} \mathrm{C}$, then incubated for $3 \mathrm{~h}$ in the presence of D-mannose $0.5 \%$, after which they were fixed in methanol $70 \%$ and stained with Giemsa stain.

\section{Enteroinvasiveness assay}

Bacteria were tested for invasiveness in HeLa cells ${ }^{18}$ and in a guinea-pig's eye by the Sereny test. ${ }^{19}$

\section{Plasmid analysis}

Plasmid DNA was extracted according to the method of Birnboim and Doly. ${ }^{20}$ After gel electrophoresis, it was stained with ethidium bromide and examined under UV light.

\section{FAS assay}

This test was performed as described by Knutton et al. ${ }^{6}$ Each isolate was examined by incubating bacteria for 3 and $6 \mathrm{~h}$ with HEp-2 cell monolayers. Quantitation of LA was performed in the $6 \mathrm{~h}$ assays. ${ }^{21}$ 

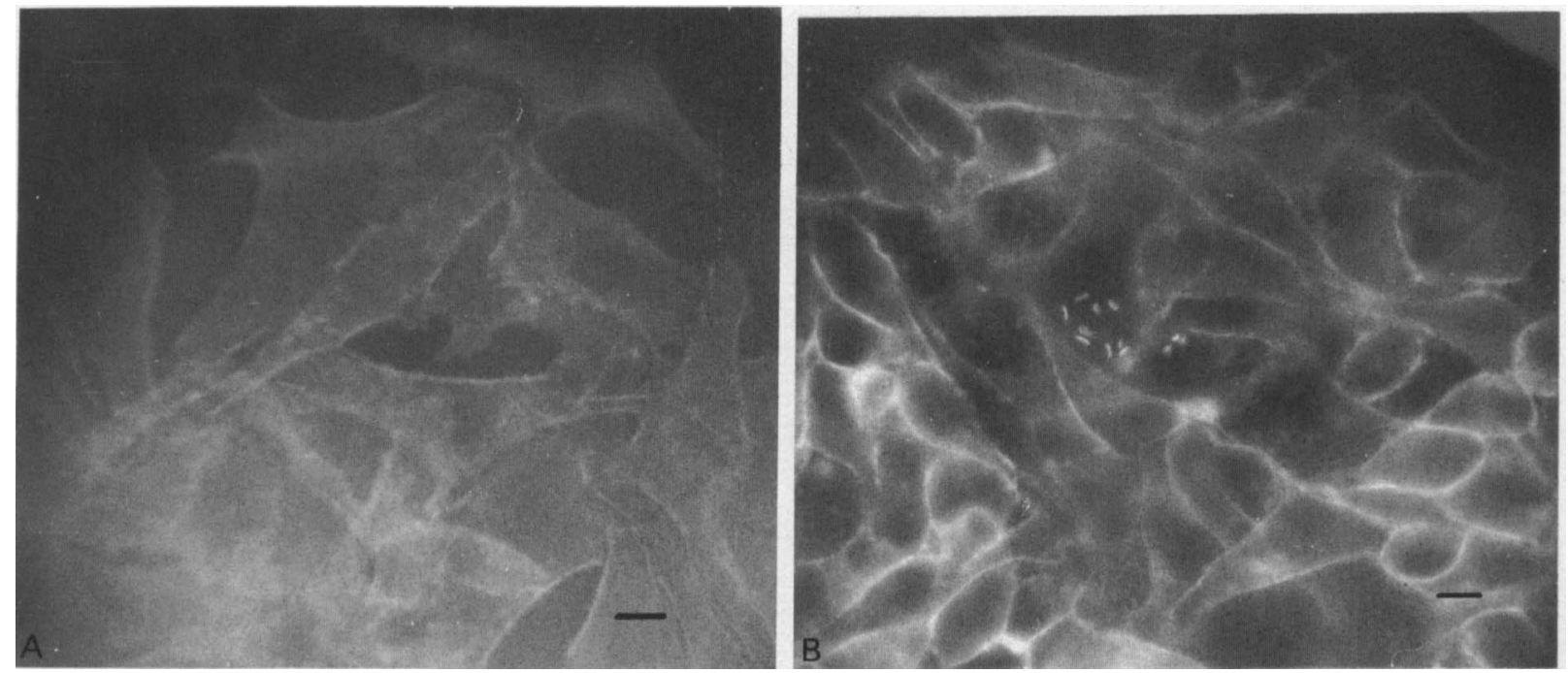

Fig. 2. Fluorescein actin staining of control HEp-2 cells (A) and H. alvei 10790 infected HEp-2 cells (B) after 6-h assay. Note the fluorescent bacterial forms in panel B which are absent in panel A. (Bar, $6 \mu \mathrm{m}$ ).

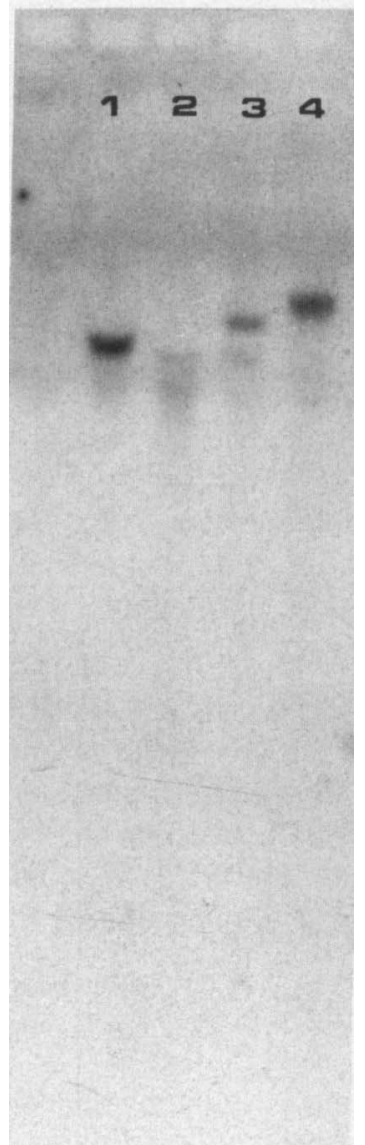

Fig. 3. Southern blot analysis of $H$. alvei $10790, H$. alvei 19982 , and EPEC strains $4084 \mathrm{C} 3$ and E2348/69 (lanes $1-4$ respectively). Chromosomal DNA was digested with EcoRI, separated by gel electrophoresis, transblotted to a nylon membrane and probed with a $1-\mathrm{kb}$ region of the eae gene of $E$. coli strain E2348/69.

\section{Rabbit ileal loop assay}

One $\mathrm{ml}$ of each $20 \mathrm{~h}$ TSB culture containing $10^{9}$ bacteria was inoculated into $c$. $10-\mathrm{cm}$-long intestinal loops of an adult New Zealand White rabbit that had previously been fasted for $48 \mathrm{~h}$. Six loops were made in each rabbit. After $20 \mathrm{~h}$, the rabbit was killed and loops were examined for fluid accumulation and other gross pathological changes. ${ }^{5}$ Portions of loops were fixed in buffered formal saline and processed for histopathological examination. All the isolates were tested in two rabbits and a non-pathogenic $E$. coli $\mathrm{K}-12$ strain was included as a negative control.

\section{EAF and eae probe tests}

The EAF probe was described by Nataro et al. (pJPN16) ${ }^{4}$ and consisted of a 1-kb BamHI-Sall restriction enzyme fragment isolated from plasmid pMAR22, that was cloned from plasmid pMAR2. The eae probe was described by Jerse et al. (pCVD434) ${ }^{10}$ and consisted of a 1-kb SalI-KpnI restriction enzyme fragment isolated from the eae gene of EPEC strain E2348/69. The probes were labelled with deoxyadenosine- $\alpha-\left({ }^{32} \mathrm{P}\right)$-triphosphate $(3000 \mathrm{mCi} / \mathrm{mmol}$; Amersham) by the random primer method. ${ }^{22}$ Hybridisation was performed as described by Echeverria et al. ${ }^{23}$

\section{Southern blot hybridisation}

Bacterial chromosomal DNA was purified by the method of Stull et al. ${ }^{24}$ and digested with EcoRI. Fragments were separated by electrophoresis on an agarose $1 \%$ gel, transferred to a nylon membrane ${ }^{25}$ and treated with the eae probe.

\section{Results}

As was found with the original strain of $H$. alvei 19982, the current six strains gave negative results in tests for the production of enterotoxins and SLTs, invasiveness and LA to HeLa cells. The original isolate and three of the current isolates (10457, 12502 and $924 / 91$ ) did not possess any plasmids. Isolate $9194 \mathrm{had}$ a plasmid of $80 \mathrm{MDa}$, isolate $38 / 90$ had four plasmids of $80,5 \cdot 8,3 \cdot 8$ and $1.0 \mathrm{MDa}$ and isolate 10790 had four plasmids of $130,4.3,4.0$ and $1.5 \mathrm{MDa}$ respectively. Like the original isolate, all the current isolates 
produced AE lesions in rabbit ileal loops (fig. 1). All isolates, including the original, also produced $\mathrm{AE}$ lesions in the FAS assay in vitro, giving a pattern of poor localised adherence (LA/P) (fig. 2).

None of the seven strains hybridised with the EAF probe. All strains hybridised with the eae probe, although the intensities of the signals obtained were weaker than those obtained with two EPEC strains, E2348/69 and 4084C3, a strain of serogroup O114.

Two H.alvei strains (19982 and 10790) were analysed further for homology with the eae probe by Southern blot hybridisation. The probe hybridised to fragments of different mol.wt in H. alvei and EPEC (fig. 3).

\section{Discussion}

$H$. alvei strains are considered to be members of the normal faecal flora. The first definitive proof of their enteropathogenicity was our demonstration of $\mathrm{AE}$ lesions in experimental models with a strain of $H$. alvei isolated from a child with diarrhoea. ${ }^{11}$ The demonstration of the same lesion with six further strains of $H$. alvei from children with diarrhoea suggests that our original observation was not fortuitous and that the prevalence of $\mathrm{AE} H$. alvei strains could be more common. Therefore, the ability of $H$. alvei to produce diarrhoea should be considered when investigating the aetiologies of diarrhoeal diseases.

Although the AE property is shared by EPEC and EHEC, ${ }^{6}$ EHEC is differentiated from EPEC by production of copious amounts of SLTs. ${ }^{26}$ Since our

\section{References}

1. Edelman R, Levine MM, from the National Institute of Allergy and Infectious Diseases. Summary of workshop on enteropathogenic Escherichia coli. J Infect Dis 1983; 147: $1108-1118$.

2. Karch H, Heesemann J, Laufs R. Phage-associated cytotoxin production by and enteroadhesiveness of enteropathogenic Escherichia coli isolated from infants with diarrhea in West Germany. J Infect Dis 1987; 155: 707-715.

3. Baldini MM, Kaper JB, Levine MM, Candy DCA, Moon HW. Plasmid-mediated adhesion in enteropathogenic Escherichia coli. J Pediatr Gastroenterol Nutr 1983; 2: 534-538.

4. Nataro JP, Baldini MM, Kaper JB, Black RE, Bravo N, Levine MM. Detection of an adherence factor of enteropathogenic Escherichia coli with a DNA probe. J Infect Dis 1985; 152: 560-565.

5. Moon, HW, Whipp SC, Argenzio RA, Levine MM, Giannella RA. Attaching and effacing activities of rabbit and human enteropathogenic Escherichia coli in pig and rabbit intestines. Infect Immun 1983; 41: 1340-1351.

6. Knutton S, Baldwin T, Williams PH, McNeish AS. Actin accumulation at sites of bacterial adhesion to tissue culture cells: basis of a new diagnostic test for enteropathogenic and enterohaemorrhagic Escherichia coli. Infect Immun 1989; 57: 1290-1298.

7. Tzipori S, Gibson R, Montanaro J. Nature and distribution of mucosal lesions associated with enteropathogenic and enterohaemorrhagic Escherichia coli in piglets and the role of plasmid-mediated factors. Infect Immun 1989; 57 : $1142-1150$

8. Levine MM, Nataro JP, Karch $\mathrm{H}$ et al. The diarrheal response of humans to some classic serotypes of enteropathogenic
$H$. alvei isolates did not produce SLTs, they resembled EPEC more closely. However, unlike most EPEC, they did not show LA with cultured cells or hybridise with the EAF probe.

All the seven $H$. alvei strains also produced AE lesions in the FAS test. This again suggested a correlation between in-vivo and in-vitro assays for $\mathrm{AE}$ lesion with $H$. alvei as found with EPEC. ${ }^{6}$ Similarity with EPEC extended to the genetic level. The eae probe constructed from a strain of EPEC hybridised with all $\boldsymbol{H}$. alvei strains, although the intensities of signals were weaker in colony hybridisation tests, perhaps suggesting a weaker homology between the sequences. In Southern blot hybridisations, the probe hybridised with fragments of differing size suggesting restriction length polymorphisms in the sequences. As carriage of this sequence corresponded with the ability of $H$. alvei to produce $\mathrm{AE}$ lesions in rabbit intestine and a positive FAS assay in HEp-2 cells, it appears that $\mathrm{AE}$ genes in $H$. alvei and EPEC may be homologous. The demonstration of homology between $\mathrm{AE}$ genes of EPEC and $H$. alvei points to either horizontal transmission of $\mathrm{AE}$ gene or the evolutionary relatedness of these two genera of bacteria.

In conclusion, the results suggest a sharing of virulence-associated properties at the phenotypic and genetic levels between $H$. alvei and EPEC, and the diarrhoeagenic potential of $H$. alvei.

This research was supported by the International Centre for Diarrhoeal Disease Research, Bangladesh (ICDDR,B), through the support of many countries and international agencies. We thank J. B. Kaper (Center for Vaccine Development, University of Maryland, Baltimore, MD, USA), for provision of EPEC attachmenteffacement probe pCVD434 and M. Haque of ICDDR,B for secretarial assistance.

Escherichia coli is dependent on a plasmid encoding an enteroadhesiveness factor. J Infect Dis 1985; 152: 550-559.

9. Knutton S, Baldini MM, Kaper JB, McNeish AS. Role of plasmid-encoded adherence factors in adhesion of enteropathogenic Escherichia coli to HEp-2 cells. Infect Immun 1989 ; 55: 78-85.

10. Jerse AE, Yu J, Tall BD, Kaper JB. A genetic locus of enteropathogenic Escherichia coli necessary for the production of attaching and effacing lesions on tissue culture cells. Proc Natl Acad Sci USA 1990; 87: 7839-7843.

11. Albert MJ, Alam K, Islam M et al. Hafnia alvei, a probable cause of diarrhea in humans. Infect Immun 1991; 59: 1507-1513.

12. World Health Organization. Programme for control of diarrhoeal diseases [CDD/83.3]. In: Manual for laboratory investigations of acute enteric infections. Geneva, World Health Organisation. 1983.

13. Griffin DE, Gemski, P. Release of Shiga toxin from Shigella dysenteriae 1 by polymyxin B. Infect Immun 1983; 40: 425-428.

14. Sack DA, Sack RB. Test for enterotoxigenic Escherichia coli using Y1 adrenal cells in miniculture. Infect Immun 1975; 11: 334-336.

15. Dean AG, Ching Y-C, Williams RG, Harden LB. Test for Escherichia coli enterotoxin using infant mice: application in a study of diarrhea in children in Honolulu. $J$ Infect Dis 1972; 125: 407-411.

16. Bitzan $M$, Karch $H$, Altrogge $H$, Strehlau J, Bläker F. Hemolytic-uremic syndrome associated with a variant shiga-like cytotoxin of Escherichia coli O111. Pediatr Infect Dis $J$ 1988; 7: 128-132.

17. Cravioto A, Gross RJ, Scotland SM, Rowe B. An adhesive factor found in strains of Escherichia coli belonging to the 
traditional infantile enteropathogenic serotypes. Curr Microbiol 1979; 3: 95-99.

18. Donnenberg MS, Donohue-Rolfe A, Keusch GT. Epithelial cell invasion: an overlooked property of enteropathogenic Escherichia coli (EPEC) associated with the EPEC adherence factor. $J$ Infect Dis $1989 ; 160: 452-459$.

19. Sereny B. Experimental keratoconjunctivitis shigellosa. Acta Microbiol Acad Sci Hung 1957; 4: 367-376.

20. Birnboim HC, Doly J. A rapid alkaline extraction procedure for screening recombinant plasmid DNA. Nucleic Acids Res 1979; 7: 1513-1523.

21. Knutton S, Phillips AD, Smith HR et al. Screening for enteropathogenic Escherichia coli in infants with diarrhea by the fluorescent-actin staining test. Infect Immun 1991; 59: 365-371.

22. Feinberg AP, Vogelstein B. A technique for radiolabelling
DNA restriction endonuclease fragments to high specific activity. Anal Biochem 1983; 132 : 6-13.

23. Echeverria P, Taylor DN, Seriwatana J, Brown JE, Lexomboon W. Examination of colonies and stool blots for detection of enteropathogens by DNA hybridization with eight DNA probes. J Clin Microbiol 1989; 27: 331-334.

24. Stull TL, LiPuma JJ, Edlind TD. A broad-spectrum probe for molecular epidemiology of bacteria: ribosomal RNA. $J$ Infect Dis 1988; 157: 280-286.

25. Southern EM. Detection of specific sequences among DNA fragments separated by gel electrophoresis. J Mol Biol 1975; 98: 503-517.

26. Levine MM. Escherichia coli that cause diarrhea: enterotoxigenic, enteropathogenic, enteroinvasive, enterohemorrhagic, and enteroadherent. J Infect Dis 1987; 155: 377-389. 